\title{
Millimeter-wave wireless links for 5G mobile networks
}

\author{
Vegas Olmos, Juan José; Tafur Monroy, Idelfonso
}

Publication date:

2015

Link back to DTU Orbit

Citation (APA):

Vegas Olmos, J. J., \& Tafur Monroy, I. (2015). Millimeter-wave wireless links for 5 G mobile networks. Paper presented at 17th International Conference on Transparent Optical Networks, Budapest, Hungary.

\section{General rights}

Copyright and moral rights for the publications made accessible in the public portal are retained by the authors and/or other copyright owners and it is a condition of accessing publications that users recognise and abide by the legal requirements associated with these rights.

- Users may download and print one copy of any publication from the public portal for the purpose of private study or research.

- You may not further distribute the material or use it for any profit-making activity or commercial gain

- You may freely distribute the URL identifying the publication in the public portal

If you believe that this document breaches copyright please contact us providing details, and we will remove access to the work immediately and investigate your claim 


\title{
Millimeter-wave wireless links for 5G mobile networks
}

\author{
J.J. Vegas Olmos, Senior Member, IEEE, and I. Tafur Monroy, Senior Member, IEEE \\ Technical University of Denmark, Department of Photonics Engineering \\ Ørsted Plads, Building 343, Kongens Lyngby, 2800, Denmark \\ e-mail:jjvo@fotonik.dtu.dk
}

\begin{abstract}
Microwave photonics and radio-over-fiber $(\mathrm{RoF})$ technologies have been investigated for over 20 years, leading to a substantial stock of know-how which is now about to be exploited in the development of the 5th generation mobile systems $(5 \mathrm{G})$. These technologies have proven mature in niche areas such as distribution of highly pure clock signals for radio telescopes, photonic-based coherent radars, and fiber optic sensing, among others. This paper will show niches in where microwave photonics can add value by providing more compact, versatile and efficient system solutions. Furthermore, different efforts in the area of radio-over-fiber for communications will be presented; particularly, remote access units for mobile backhauling or point-to-point wireless links driven by photonic technologies.
\end{abstract}

Keywords: microwave photonics, millimetre-wave communications, mobile networks, optical communications 